\title{
Editorial:
}

\section{Research Inquiry for Whom and for What Purpose?}

\section{Dolana Mogadime}

Editor-in-chief

Brock University

What drives research inquiry? Why do researchers formulate an inquiry as they do? How do we support the development of improved human relationships through research? These are a set of questions uniquely answered by James A. Bernauer, Mary Pat Bernauer and Patrick Bernauer (2017) in their coauthored collaborative article featured in this issue entitled, "A Family Affair: Caring in Teaching and Implications for Teacher and Researcher Preparation." The Bernauers' family inquiry sets the stage for a better understanding about the role of care in education. Of interest, are recommendations the authors advance with reference to improving teacher education. Connor Kirwan Warner and Heidi L. Hallman's (2017) article entitled, "A Communities of Practice Approach to Field Experiences in Teacher Education," delves into questions about how inquiry can enrich and improve the practicum experience for teacher candidates. They argue for the incorporation of Community of Practice $(\mathrm{CoP})$ as a shared goal for both teacher educators and the school based teachers who mentor student teachers. Using two case studies drawn from a larger set of interviews with 17 teacher candidates, the authors provide a "Continuum of Participation in Community of Practice" (p. 21). Locating the case studies on this continuum facilitates an angle through which to better understand and articulate how and why a given student is located differentially. The study's recommendations suggest a stronger partnership and collaboration between universities and schools. Further, such as suggestion corroborates with directives from both the Accord on Initial Teacher Education (ACDE, 2016) in Canada as it does the Council for the Accreditation of Educator Preparation (CAEP) in the United States.

Sarah Burm and Dawn Burleigh's (2017) inquiry, "Non-Indigenous Women Teaching Indigenous education: A Duoethnographic Exploration of Untold Stories about their teaching practices," invites the reader into their parallel journey into becoming, living and sustaining authenticity within their dual roles as non-Indigenous educators teaching about Indigenous education. Imploring the duoethnographic inquiry approach, allows the authors to engage in critical self-reflection on their teaching positions with the view to become personally accountable to living allyship. Put simply, they challenge one another to walk the talk, through delving into their 'untold stories.' Burm and Burleigh utilize what they term as 'four conversational sites.' These are places and spaces in which they socially interact as scholars, educators and people, daily. The significance of this work is that the duoethnographic inquiry read with the authenticity in which it is written holds potential to challenge the reader educator to undergo a similar journey toward a better understanding about our multiple roles in learning, supporting and responding to the call to Indigenize Canadian universities. Stephanie Tuters' (2017) inquiry entitled, "What Informs and Inspires the Work of Equity Minded Teachers, " focuses on questions about what encourages and motivates teachers to engage in equity based approaches in teaching. The inquiry draws from interviews with 15 teachers, located in three different school boards. Tuter's 
contribution is important within the current milieu, particularly in Ontario, with the equity and inclusive strategy on one hand and lack of research data on the personal contexts for why teachers become interested in doing equity work. Her argument about 'equity minded' educators' unearths the inner terrain of the teacher to arrive at how critical incidents in their life stories inform their interest in equity. Furthermore, this knowledge has implications for teacher education and teachers in the field. Tuter points out that her research findings can be used as a baseline for further investigations into what informs teachers decisions to become aligned with equity based approaches. As well, it may encourage educators to take-up an interest in becoming equity minded teachers. Kristen Ferguson, Colin Mang and Lorraine Frost's (2017) inquiry about "Teacher stress and support usage" suggests strategies to attain work life balance need greater attention. The researchers used 264 surveys from teachers in northern Ontario to examine "the impact of social supports based on the frequency with which teachers spoke to others about stress" (p. 63). The study is significant because teacher attrition is becoming an area of concern as increasing research reports identify that improved supports could reduce attrition. The implications of the study make known the role that teacher education programs can play in instilling the importance of stress management and well-being as an integral part of the professional learning. Further, they argue that the focus on well-being needs to begin in teacher education but continue throughout teachers' careers via ongoing professional learning contexts.

Robert Scott Liggett's (2017) inquiry, "The Impact of Use of Manipulatives on the Math Scores of Grade 2 Students." is contextualized within "the pressure on schools, teachers, and students to improve test scores" (p. 87). This is made evident in media coverage highlighting the need for improvement among Saskatchewan students' performance in math. Liggett's contribution advances discussion and consideration for the possibility of using mathematical manipulatives to support improved math test scores as well as students attitude toward math. Forty-three Grade 2 students participated in the study. Liggett's review of the literature accounts for decade-long debates regarding mathematics pedagogy in relation to the uses of manipulates. Liggett focuses the reader on the goals of his research within such debates when he states,

School professionals are constantly looking for methods to improve student learning. Achieving this will require effort and the use of multiple strategies or methods. The goal of this quasi-experimental study was to provide information about the value of manipulatives as another tool that is available to assist educators in the endeavor of improving student learning. (Liggett, 2017, p. 88-89)

Liggett argues that given we find ourselves within an era that demands both school boards and teachers improve test results, the uses of manipulatives should be taken as a serious and viable solution, particularly when backed by research inquiry. Educators and school boards will be better served by having knowledge of the debates and how Liggett's experiential research fits within the larger discussion of solutions. Donna Kotsopoulos et al., (2017) in their coauthored article entitled, "The Diagnosis Dilemma: Dyslexia and Visual-Spatial Ability," provide an inquiry that makes an important point regarding research participants, research designs and equity. The final section of the article is both intriguing and provides scope for new research emerging, as a result of the inquiry. While this article is primarily a commentary appended to the beginnings of a research report that took a different turn, it makes a contribution and provides an interesting set of questions in need of further investigation by the field. 
Coauthors, Yusuf Demir and Kemal Sinan Özmen (2017) in "Exploring Native and Non-Native EFL Teachers' Oral Corrective Feedback Practices: An Observational Study,” draw from Demir's doctoral research study in Turkey, based on classroom observations and interviews conducted with seven native and non-native English-speaking teachers NESTs and seven NNESTs. While the coauthors argue that "oral corrective feedback (OCF) is an interactional classroom phenomenon which frequently occurs in foreign language classes and has gained growing momentum in Second Language Acquisition (SLA) research in recent years," (p. 111) Demir and Özmen's inquiry questions the fact that the role of the teacher as a variable in facilitating OCF has become underresearched and marginalized. The authors make known the limitations in professional knowledge when they point out that teacher education provides limited opportunities for student teachers to develop Second Language pedagogies. Their research therefore attempts to fill this gap. All the inquiries featured in the current issue, based in Canada, the United States, and Turkey, unanimously call for teacher education programs as well as stakeholders to oversee ongoing professional learning for teachers, to provide new and improved content to ameliorate the concerns, issues and problems raised in their studies. As such, they provide research results that are of interest to both teacher education institutions as well as school-based partners vested with supporting ongoing professional learning among teachers.

\section{References}

Association of Canadian Deans of Education (ACED) (2016). Accord on initial teacher education. Retrieved from http://www.csse-scee.ca/docs/acde/ACDE_Accord_on_Initial_Teacher_Education.pdf

Bernauer, J. A., Bernauer, M. P., \& Bernauer, P. (2017). A Family Affair: Caring in Teaching and Implications for Teacher and Researcher Preparation. Brock Education: A Journal of Educational Research and Practice, 26(2), 4-15.

Burm, S., \& Burleigh, D. (2017). Non-Indigenous Women Teaching Indigenous education: A Duoethnographic Exploration of Untold Stories about their teaching practices. Brock Education: A Journal of Educational Research and Practice, 26(2), $34-46$.

Council for the Accreditation of Educator Preparation (CAEP). (2015). Standard 2: Clinical partnerships and practice. Retrieved from http://caepnet.org/standards/standard-2

Demir, Y., \& Özmen, K. S. (2017). Exploring Native and Non-Native EFL Teachers' Oral Corrective Feedback Practices: An Observational Study. Brock Education: A Journal of Educational Research and Practice, 26(2), 111-129.

Ferguson, K., Mang, C., \& Frost, L. (2017). Teacher stress and support usage. Brock Education: A Journal of Educational Research and Practice, 26(2), 62 - 86.

Kotsopoulos, D. et al., (2017). The Diagnosis Dilemma: Dyslexia and Visual-Spatial Ability. Brock Education: A Journal of Educational Research and Practice, 26(2), $102-110$.

Liggett, R. S. (2017) The Impact of Use of Manipulatives on the Math Scores of Grade 2 Students. Brock Education: A Journal of Educational Research and Practice, 26(2), 87 - 101.

Tuters, S. (2017). What Informs and Inspires the Work of Equity Minded Teachers. Brock Education: $A$ Journal of Educational Research and Practice, 26(2), 47 - 61.

Warner, C. K., \& Hallman, H. L. (2017). A Communities of Practice Approach to Field Experiences in Teacher Education. Brock Education: A Journal of Educational Research and Practice, 26(2), 16 33. 